\title{
Chapter 16 \\ Bioformulation of Microbial Biocontrol Agents for a Sustainable Agriculture
}

\author{
Ana Bejarano and Gerardo Puopolo
}

\subsection{Current State of Biocontrol Strategies}

Within the stresses that crop plants may face during producing cycles and storage, the ones caused by the attacks of pests and pathogenic (micro)organisms (bacteria, fungi, nematodes, oomycetes, protists and viruses) represent a major constraint on crop production in all agricultural and horticultural systems. Although quantifying a precise percentage is difficult, crop losses to pests and pathogens are estimated at up to $40 \%$ for total global food production (IPPC 2017). As a consequence, higher quantities of chemical pesticides are applied annually and the use of 4,088,167.77 tonnes of pesticides was estimated in 2016 (FAOSTAT).

It is undeniable that the management of plant diseases plays a key role in modern crop production. Yet, disease management based mainly on chemical inputs is highly detrimental for the environment, animals and human health. The increasing awareness of the negative impact of chemical pesticides produced a major interest in finding ecologically beneficial alternatives with less environmental and human impacts. In this regard, the application of microbial biocontrol agents (BCAs), usually bacteria and fungi, to prevent infections by plant pathogens, both pre-harvest and post-harvest, has attracted significant interest from the scientific community.

A graph of all literature released in this research area for agriculture between 1974 and 2018 with the term "biocontrol" is shown in Fig. 16.1. This indicates a constant increase of scientific publications and patents over this period, with the highest values registered in 2015 and 2017, respectively. Considering "Science Technology" as the only Research Domain, a total of 6,575 documents were counted

\footnotetext{
A. Bejarano $(\triangle) \cdot$ G. Puopolo

Center of Agriculture, Food, Environment, University of Trento, San Michele all'Adige, Italy

Department of Sustainable Agro-Ecosystems and Bioresources, Research and Innovation Centre, Fondazione Edmund Mach, San Michele all'Adige, Italy

e-mail: ana.bejaranoramos@fmach.it; gerardo.puopolo@fmach.it
} 


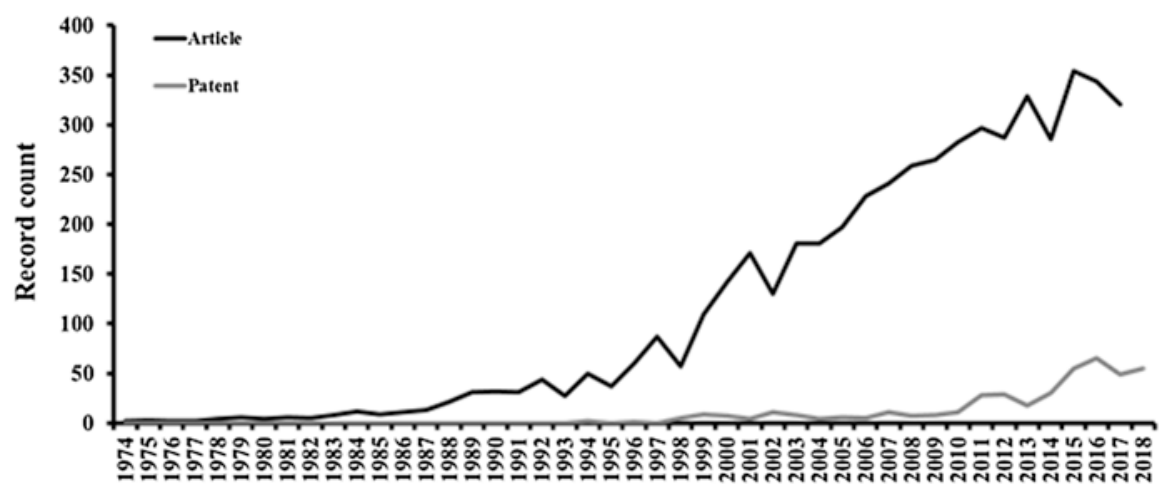

Fig. 16.1 Number of documents published in the period 1974-2018. Literature search was carried out in Web of Science using Advanced Search with the formula: TI = biocontrol AND $\mathrm{SU}=$ agriculture

to date, and most of these were represented by articles $(5,175)$, meetings $(1,380)$ and patents (429). Yet, most of them are just focused on the selection and identification of novel BCAs able to effectively protect plants from the attacks of plant pathogens and the characterization of their modes of action.

BCAs may control plant pathogens directly by establishing an intimate contact with the host pathogen and/or indirectly, when no physical contact occurs between the microorganisms. In most cases, BCAs are able to control plant pathogens both directly and indirectly. Within the indirect control, the ability to rapidly colonize and occupy the phytosphere is one of the most important requisites of each BCA. The colonization allows for pre-emptively occupation of the ecological niches (infection sites) and rapidly consume available substrates (i.e., plant exudates) making pathogen infections more difficult to occur. This ability is particularly important in plant niches where the nutrient availability is scarce, such as the phyllosphere. Lindow (1987) demonstrated that the effective colonization of foliar plant tissues by an ice nucleation-deficient Pseudomonas (Ps.) syringae strain on pears in the field resulted in a reduced colonization of leaves, flowers, and young fruits by the phytopathogenic bacterium Erwinia amylovora, when compared with untreated pear trees. Other mechanisms involved in plant protection include the antibiosis through the emission of volatile organic compounds (VOCs). For example, the VOC 2-phenethyl alcohol emitted by Aureobasidium pullulans L1 and L8 was highly effective in reducing the conidial germination of the post-harvest pathogenic species Botrytis cinerea, Colletotrichum acutatum, Penicillium digitatum, P. expansum and P. italicum (Di Francesco et al. 2015).

Competition for micronutrients plays an important role in the capacity of BCAs in controlling plant pathogens in the rhizosphere. Of these, iron is extremely limited in the rhizosphere due to the low solubility of the ferric form. Thus, efficiency in iron uptake contributes to the ability of BCAs to colonize the plant rhizosphere and 
displace plant pathogens from potential infection sites. Microorganisms chelate iron from the environment through the production and release of secondary metabolites named siderophores (Khan et al. 2018). In this regard, siderophores produced by plant beneficial bacteria showed a higher affinity for iron than the siderophores produced by phytopathogenic fungi. In particular, biocontrol bacteria belonging to the genus Pseudomonas showed a high efficiency in protecting plants through the chelation of iron in the rhizosphere (reviewed in Haas and Défago 2005).

Some BCAs are also able to trigger Induced Systemic Resistance (ISR), an important resistance mechanism, that allows plants to become primed to respond rapidly to attacks by pathogenic microorganisms and phytophagous insects (Pieterse et al. 2014). Bacillus spp., for instance, overcome plant defence lines regulated by salicylic acid (SA) and jasmonic acid (JA)/ethylene (ET) signalling pathways through the production of cyclic lipopeptides of the families of iturins, fengycins and surfactins (Ongena et al. 2007; Chowdhury et al. 2015; Farace et al. 2015). Recently, Wu et al. (2018) showed that the application of B. amyloliquefaciens FZB42 on Nicotiana benthamiana roots reduced the disease symptoms caused by Phytophthora $(P h$.) nicotianae. This reduction was related to the up-regulation of defence-related genes of the SA and JA/ET dependent signalling pathways. Likewise, omycete BCAs were able to protect the plant indirectly, as found for Pythium (Py.) oligandrum which was able to control Fusarium oxysporum f. sp. radicis-lycopersici in tomato and $B$. cinerea in grapevine. The ability of Py. oligandrum to activate the defence mechanisms in plants is associated with the production of oligandrin, a protein involved in the activation of ISR mechanisms (Benhamou et al. 2001; Mohamed et al. 2007).

Py. oligandrum is also known as a mycoparasite able to control plant pathogens by establishing intimate contact with the host pathogen and attacking their living hyphae (Rey et al. 2008). In general, mycoparasitism is characterised by the release of lytic enzymes (chitinases, glucanases, proteases and cellulases) involved in the degradation of the main components of fungal and oomycete cell walls. The production of lytic enzymes is also typical of Coniothyrium minitans. In contrast to $P y$. olygandrum, the activity of the mycoparasite $C$. minitans relies more on the production of chitinases and $\beta-1,3$ glucanases (Whipps and Gerlagh 1992) and antibiotics, such as macrosphelide A, a macrolide active against Gram-positive bacteria, fungi and oomycetes (Tomprefa et al. 2009). Similarly, Trichoderma spp. are able to parasitize and consequently control a plethora of plant pathogenic fungi and oomycetes through the secretion of numerous chitinases and $\beta-1,3$-glucanases, and secondary metabolites with toxic activity against pathogens, including volatile antibiotics (i.e., 6-pentyl-a-pyrone), water-soluble compounds (i.e., heptedelic acid) and toxic oligopeptides (Vinale et al. 2008). Surprisingly, the production of antibiotics is not encompassed in the mode of action of the mycoparasite Ampelomyces quisqualis, a picnidial ascomycete which is able to grow and invade mycelial structures (hyphae, conidiophores) of powdery mildew pathogens (Kiss 2008). 
Production of lytic enzymes and antibiotics is also typical of the predation implemented by BCAs belonging to the genus Lysobacter (Puopolo et al. 2018). Thus, L. capsici AZ78 is able to colonize Ph. infestans mycelium through twitching motility and feed on the dead mycelium through the production of cell wall degrading enzymes. Moreover, $L$. capsici AZ78 has been associated with the activation of apoptosis processes in Ph. infestans, probably due to the release of a tetramic acidcontaining macrolactam (Tomada et al. 2017). Additionally, Lysobacter BCAs may also control plant pathogens without establishing an intimate contact by stimulating the plant defence response or by releasing a relevant set of antibiotic compounds into the environment (Kilic-Ekici and Yuen 2003; Islam et al. 2005; Li et al. 2008; Puopolo et al. 2014).

The synthesis and release in the environment of antibiotics is a trait studied in detail in BCAs belonging to Bacillus and Pseudomonas genera. Characterization of the two BCAs Ps. fluorescens 2-79 and Ps. chlororaphis 30-84, both isolated from suppressive soils in USA, led to the determination of the direct role played by phenazines against Gaeumannomyces graminis var. tritici, causal agent of wheat take all (Thomashow et al. 1990). Pseudomonad BCAs may also release other compounds with antimicrobial activity into the rhizosphere, like cyclic lipopeptide viscosinamide (Thrane et al. 2000). Production of antifungal cyclic lipopeptides, particularly of iturin and fengycin families, is typical of Bacillus spp. (Koumoutsi et al. 2004; Leclère et al. 2005). Accumulation of antibiotics was also ascribed to other bacterial biocontrol agents, such as Burkholderia (Bu.) cepacia B37 and Erwinia herbicola B247, which produce pyrrolnitrin and herbiconlin A, respectively (Kempf et al. 1993; Burkhead et al. 1994).

Despite the impressive body of knowledge produced so far on the ability of BCAs to protect crops, few microorganisms are registered as active substances in the EU at the time of the writing, and most of them are strains of Trichoderma and Bacillus spp. (Table 16.1).

What are the causes that are determining this gap between studies on BCAs and their translation into commercial products in the EU? In our opinion, one of the major reasons is that quite often BCAs characterised at the laboratory level fail to fulfil all the requirements of the registration process, such as eco-toxicological risks. Another possible answer can be found in the inconsistency of the efficacy of BCAs applied in the field, which may be due to the poor attention that the scientific community gives to the research focused on their production, formulation and delivery. Based on this limited attention, we aimed at drawing a general workflow that may be adopted by the scientific community for the formulation of BCAs providing information on the technologies and methods that can be used to develop novel commercial BCAs which may be effective for field use (Fig. 16.2). 
Table 16.1 List of biocontrol microorganisms approved as active substance in the European Union

\begin{tabular}{|c|c|}
\hline Biocontrol microorganisms & Category \\
\hline Ampelomyces quisqualis $\mathrm{AQ} 10^{\mathrm{a}}$ & Fungicides \\
\hline $\begin{array}{l}\text { Aureobasidium pullulans DSM } 14940 \text { and DSM } \\
14941\end{array}$ & Bactericides and fungicides \\
\hline Bacillus amyloliquefaciens QST 713 & Bactericides and fungicides \\
\hline Bacillus amyloliquefaciens MBI 600 & Fungicides \\
\hline Bacillus amyloliquefaciens FZB24 & Fungicides \\
\hline Bacillus amyloliquefaciens subsp. plantarum D747 & Fungicides \\
\hline Bacillus firmus $\mathrm{I}-1582$ & Nematicides \\
\hline Bacillus pumilus QST 2808 & Fungicides \\
\hline Candida oleophila $\mathrm{O}$ & Fungicides \\
\hline Clonostachys rosea $\mathrm{J} 1446$ & Fungicides \\
\hline Coniothyrium minitans CON/M/91-08 (DSM 9660) & Fungicides \\
\hline Paecilomyces lilacinus 251 & Nematicides \\
\hline Pseudomonas chlororaphis MA342 & Fungicides \\
\hline Pseudomonas sp. DSMZ 13134 & Fungicides \\
\hline Pythium oligandrum M1 & Fungicides \\
\hline Streptomyces K61 & Fungicides \\
\hline Streptomyces lydicus WYEC 108 & Bactericides and fungicides \\
\hline Trichoderma asperellum ICC012, T25 and TV1 & Fungicides \\
\hline Trichoderma asperellum T34 & Fungicides \\
\hline Trichoderma atroviride IMI 206040 and T11 & Fungicides \\
\hline Trichoderma atroviride $\mathrm{I}-1237$ & Fungicides \\
\hline Trichoderma atroviride $\mathrm{SC} 1$ & Fungicides \\
\hline Trichoderma gamsii ICC080 & Fungicides \\
\hline Trichoderma harzianum T-22 and ITEM 908 & Fungicides \\
\hline Trichoderma polysporum IMI 206039 & Fungicides \\
\hline
\end{tabular}

anformation source: http://ec.europa.eu/food/plant/pesticides/eu-pesticides-database/public/?even $\mathrm{t}=$ homepage $\&$ language $=\mathrm{EN}$

\subsection{Formulations of BCAs}

Formulation of BCAs is a multistep process that begins immediately after the selection of the most promising BCA for intended effect on a target pathosystem, and it basically consists on combining viable microorganisms with carriers and adjuvants to produce high-quality preparations of stable shelf life and proven efficacy. From a technical point of view, this requires in depth knowledge of the ecology and biology of the BCA, the pathosystem, the environment and the application niche, along with considerations of the plant growth stage, inoculation techniques and types of irrigation systems involved in the agrifood system. 


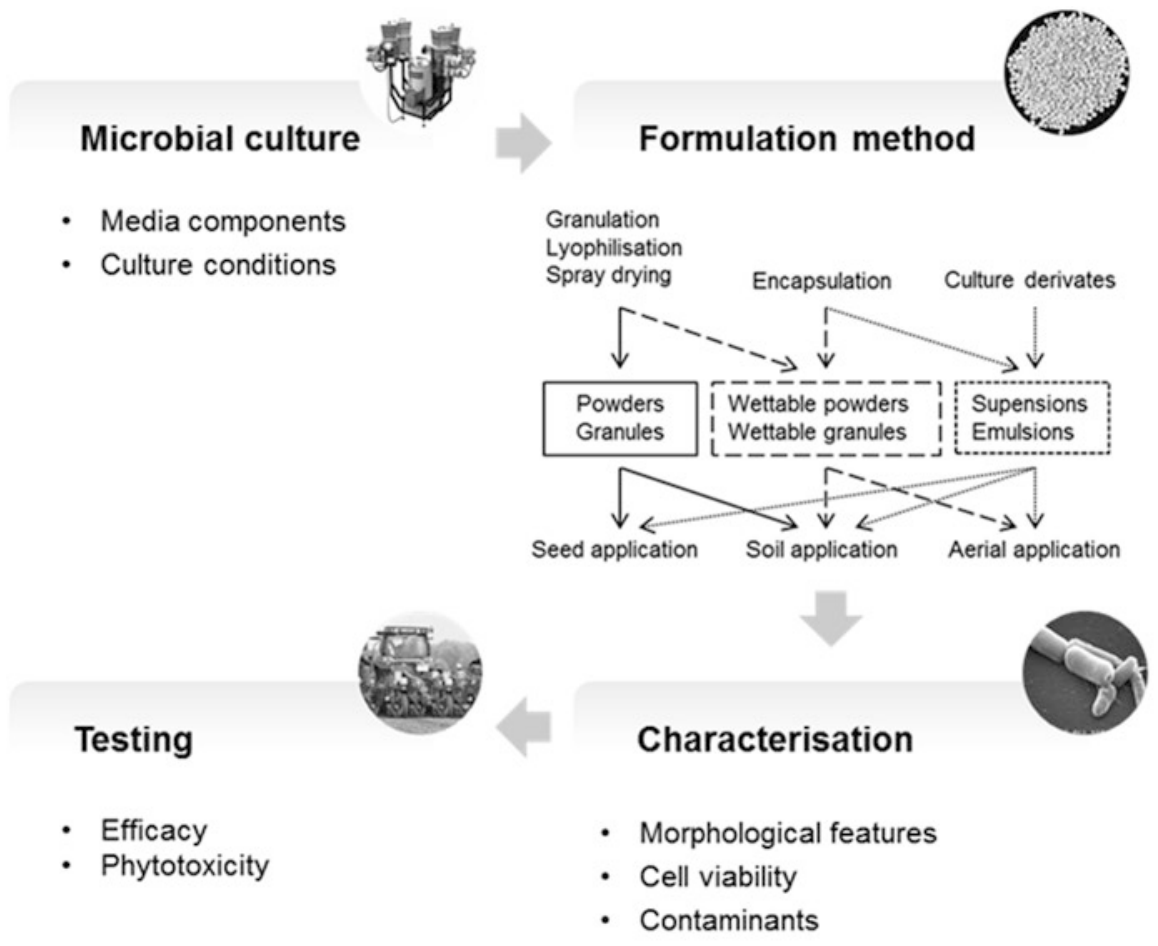

Fig. 16.2 General workflow of the procedures involved in the development of microbial biocontrol formulations

\subsubsection{Production of Microbial Biocontrol Agents}

Biomass production is the first—crucial-step of formulation of BCAs. Culturing conditions determine population densities at the time of harvest and also influence the viability and fitness of microbes during formulation, storage, and application. These are however specific for each microbial strain and need to be screened carefully for improving final performance of microorganisms in the field.

Standard laboratory culture media, rich in peptone, yeast extract, and tryptone allow for the production of a high biomass of BCAs on a small scale; however, their use for large-scale production is not economic and unsuitable. A combination of traditional components with low-cost substrates contribute to reducing fermentation costs and have been successfully used for the production of some BCAs (reviewed in Lobo et al. 2019). Industrial by-products such as cheese whey, corn steep liquor, soybean bran, wheat bran, barley fibre, fishmeal, molasses, composts or wastewater sludge may all serve as good low-cost alternative carbon and nitrogen sources. Hence, different composts and wastewater derivatives have been used for fermentation of B. amyloliquefaciens and Paenibacillus polymyxa (Lobo et al. 2019). 
Thermo- and osmo-protectants such us glycerol, disaccharides or amino acids might be additionally included in the culture media to enhance cell survival in events of osmotic stress, dehydration, and high temperatures.

Besides culture media, optimal culture parameters, including dissolved oxygen, temperature, $\mathrm{pH}$, and mixing speed need to be identified. Dissolved oxygen in liquid fermentation systems is often between $90 \%$ and $100 \%$ with a temperature of $25-28{ }^{\circ} \mathrm{C}$ for biocontrol bacteria production. Harvesting cells during the stationary phase generally provides higher protection against environmental stress than in the lag and exponential phases due to the depletion of nutrients and accumulation of toxic metabolites (Morgan et al. 2006). For some filamentous fungal BCAs solid substrate fermentation has been necessary to obtain the economic threshold production of propagules for downstream processing. Again, in this case heat dissipation, maintaining aerobic conditions and maximising sporulation are all critical. The use of biofilms was proposed as a possible means of producing effective biocontrol inocula.

\subsubsection{Formulation Methods}

BCAs can be formulated in many forms, although commercial biocontrol formulations conventionally come only in a very few variations: powder, granulated or liquid forms (Keswani et al. 2016). For each of these, a wide range of carriers and adjuvants are available. Some examples of commercially available microbial biocontrol products in Europe are given in Table 16.2.

\subsubsection{Powder and Granular Formulations}

Powder and granular formulations are produced using soil and/or organic or inorganic carriers. They mainly differ from each other in their particle sizes. While powder inoculants have variable particle sizes of about a few hundreds of micrometres, granules particle sizes usually range between $0.1-2.5 \mathrm{~mm}$ (microgranules, 100-600 $\mu \mathrm{m}$; fine granules, 0.3-2.5 mm). However, larger granules might be produced (up to $6 \mathrm{~mm}$ ).

To obtain powder formulations, microorganisms are simply mixed with a carrier (finely ground) and adjuvants in a blender until obtaining a homogeneous mixture, or the actual granules are ground up into a fine powder. This can be done manually or mechanically by using milling machines. In addition, powders can also be produced using lyophilisation and spray drying. Lyophilisation has been widely used to preserve the viability of biocontrol bacterial like Ps. fluorescens (Cabrefiga et al. 2014) and Pseudomonas spp. (Stephan et al. 2016). It is considered a relatively gentle dehydration method in which cells are initially incorporated into a matrix that protects them from damage during freezing and drying. Spray-drying involves the atomization of a liquid matrix into a drying chamber with a flow of hot air, 
Table 16.2 Examples of microbial biocontrol formulations commercialized in Europe

\begin{tabular}{|c|c|c|c|}
\hline $\begin{array}{l}\text { Trade name and } \\
\text { company }\end{array}$ & Microorganism & Formulation type & Application \\
\hline $\begin{array}{l}\text { AQ } 10 \text { WG } \\
\text { CBC EUROPE }\end{array}$ & $\begin{array}{l}\text { Ampelomyces } \\
\text { quisqualis } \mathrm{AQ} 10\end{array}$ & $\begin{array}{l}\text { Wetttable } \\
\text { granules }\end{array}$ & Foliar pray \\
\hline $\begin{array}{l}\text { Amylo-X LC } \\
\text { Mitsui } \\
\text { AgriScience } \\
\text { international }\end{array}$ & $\begin{array}{l}\text { Bacillus } \\
\text { amyloliquefaciens } \\
\text { subsp. plantarum } \\
\text { D747 }\end{array}$ & Liquid & $\begin{array}{l}\text { Soil spray, soil drench, soil } \\
\text { irrigation }\end{array}$ \\
\hline $\begin{array}{l}\text { Cerall } \\
\text { BioAgri }\end{array}$ & $\begin{array}{l}\text { Pseudomonas } \\
\text { chlororaphis } \\
\text { MA342 }\end{array}$ & $\begin{array}{l}\text { Flowable } \\
\text { suspension }\end{array}$ & Seed coating \\
\hline $\begin{array}{l}\text { Serenade max } \\
\text { Bayer } \\
\text { CropScience }\end{array}$ & $\begin{array}{l}\text { Bacillus } \\
\text { amyloliquefaciens } \\
\text { QST } 713\end{array}$ & Wettable powder & Foliar spray \\
\hline $\begin{array}{l}\text { Serenade ASO } \\
\text { Bayer } \\
\text { CropScience }\end{array}$ & $\begin{array}{l}\text { Bacillus } \\
\text { amyloliquefaciens } \\
\text { QST } 713\end{array}$ & $\begin{array}{l}\text { Suspension } \\
\text { concentrate }\end{array}$ & Foliar spray \\
\hline $\begin{array}{l}\text { Contans WG } \\
\text { Bayer } \\
\text { CropScience }\end{array}$ & $\begin{array}{l}\text { Coniothyrium minitans } \\
\text { CON/M/91-08 }\end{array}$ & $\begin{array}{l}\text { Wetttable } \\
\text { granules }\end{array}$ & Soil spray \\
\hline $\begin{array}{l}\text { FZB24 } \\
\text { AbiTEP }\end{array}$ & $\begin{array}{l}\text { Bacillus } \\
\text { amyloliquefaciens } \\
\text { FZB24 }\end{array}$ & $\begin{array}{l}\text { Liquid, wettable } \\
\text { powder, dry } \\
\text { powder }\end{array}$ & $\begin{array}{l}\text { Soil spray, soil drench, seed } \\
\text { dipping, seed coating (seed } \\
\text { spraying or dry powder in seed } \\
\text { hopper) }\end{array}$ \\
\hline $\begin{array}{l}\text { Proradix } \\
\text { Sourcon Padena }\end{array}$ & $\begin{array}{l}\text { Pseudomonas spp. } \\
\text { DSMZ } 1313\end{array}$ & Wettable powders & In-furrow \\
\hline $\begin{array}{l}\text { Binab T } \\
\text { Bio-innovation } \\
\text { AB }\end{array}$ & $\begin{array}{l}\text { Trichoderma atroviride } \\
\text { IMI } 206040 \\
\text { Trichoderma } \\
\text { polysporum } \\
\text { IMI } 206039\end{array}$ & $\begin{array}{l}\text { Wettable powder, } \\
\text { pellet }\end{array}$ & On wound \\
\hline $\begin{array}{l}\text { Mycostop } \\
\text { Vedera Oy }\end{array}$ & $\begin{array}{l}\text { Steptomyces } \\
\text { griseoviridis } \\
\text { K61 }\end{array}$ & $\begin{array}{l}\text { Dry spores and } \\
\text { mycelium }\end{array}$ & $\begin{array}{l}\text { Soil spray, soil drench, soil } \\
\text { irrigation, seed coating (dry } \\
\text { powder in seed hopper) }\end{array}$ \\
\hline $\begin{array}{l}\text { Trichox WP } \\
\text { Biox }\end{array}$ & Trichoderma harizanum & Wettable powder & Soil spray \\
\hline $\begin{array}{l}\text { Trichostar } \\
\text { Biohelp }\end{array}$ & $\begin{array}{l}\text { Trichoderma harizanum } \\
\text { T58 }\end{array}$ & Liquid & Soil spray \\
\hline $\begin{array}{l}\text { Asperello T34 } \\
\text { biocontrol } \\
\text { Biobest }\end{array}$ & $\begin{array}{l}\text { Trhichoderma } \\
\text { asperllum } \\
\text { T34 }\end{array}$ & Wettable powder & $\begin{array}{l}\text { Soil spray, soil irrigation, root } \\
\text { dipping }\end{array}$ \\
\hline $\begin{array}{l}\text { Prestop } \\
\text { Biobest }\end{array}$ & $\begin{array}{l}\text { Clonostachys rosea } \\
\mathrm{J} 1446\end{array}$ & Wettable powder & $\begin{array}{l}\text { Soil spray, soil irrigation, } \\
\text { in-furrow }\end{array}$ \\
\hline
\end{tabular}


which induces rapid evaporation of water, leading to the formation of dry particles. This formulation method has, however, proven only applicable for robust sporeforming biocontrol bacteria, such as B. subtilis (Yánez-Mendizábal et al. 2012).

Granules are usually made by wet granulation procedures. This consists of mixing, spraying or impregnating a powder carrier with a microbial solution, sometimes amended with an adhesive, and shearing or extruding the resulting matrix through a sieve to obtain the desired particle size. Granules are subsequently allowed to dry using air-drying in standard conventional ovens or fluidized bed-drying. Granulation can be also performed in fluidized beds prior to drying. For this, BCAs are sprayed into the moving mass of carriers and the resulting agglomerates are then dried by the upward blowing stream of air. Alternatively, granules can be produced by dry granulation (briquetting). In brief, microorganisms are incorporated into a powder mix and pressed using roller compactors.

Wettable powders and water-dispersible granules are formulated as described above, but anionic dispersants and wetting agents must be included in the formulation. Wettable powders and water-dispersible granules generally consist of 50-80\% carrier, 15-45\% diluent, 1-10\% dispersant (this might be higher in the case of water-dispersible granules), and 3-5\% of a wetting agent (Brar et al. 2006). In general, the final concentration of the microorganisms in granules is about $5-20 \%$, while in powders is $<10 \%$ (Brar et al. 2006).

Peat is the carrier of choice for bacterial-based biofertilisers and it is also popular for soil applications and seed coating of BCAs (Keswani et al. 2016). Both biocontrol bacteria and fungi have been formulated in peat. For instance, peat-based formulations of B. amyloliquefaciens, B. subtilis, P. polymyxa, Pseudomonas sp. and Ps. fluorescens have provided control of soil borne pathogens (Abbasi et al. 2016). Additionally, peat can be amended with other substrates, including lignite, charcoal, coir dust, compost, sugarcane bagasse and composts. Charcoal, sand, sawdust, and sugarcane bagasse were used as carriers for inoculants of Ps. fluorescens (Arora et al. 2008).

Inorganic carriers obtained from inorganic minerals or polymers include talc and kaolin have also been used for the control of soil-borne pathogens (Amer and Utkhede 2000; Abbasi et al. 2016). With respect to polymeric inoculants, the ultimate polymer included in agricultural and environmental formulations is alginate. Although other natural polysaccharides like agar, $\alpha$ - and k-carrageenan, agar/agarose, gellan gum, guar gum, bean gum, arabic gum, starch and starch-based materials, cellulose and derivatives (carboxymethylcellulose (CMC), ethylcellulose), xanthan, pectin, chitosan; polypeptides such as poly L-lysine; proteins like gelatine or whey; lipids like waxes; or lignin can also be used. In addition, a wide variety of synthetic polymers and copolymers are available (Vemmer and Patel 2013). Additional additives have included protective compounds such as sugars, polymers, and amino acids in powders and granules to enhance the shelf-life of the microorganisms (reviewed in Berninger et al. 2018). 


\subsubsection{Cell Immobilization Systems}

The progress made in powder and granules technology has paved the way for the implementation of cell immobilization technology in microbial pest control. Of these, encapsulation has proven to be the most promising for BCAs. This allows for the immobilization of cells in a polymeric shell or capsule. Usually, the capsules are produced by forming droplets from liquids, by either dripping or emulsifying and solidifying the liquid droplets to form particles. Different techniques, including thermal and ionic gelation, co-acervation and solvent extraction/evaporation, spray drying, sol-gel immobilization, interfacial polymerization, ionic polymer coating, and layer-by-layer coating have been used to define the size, shape, and the texture of the capsules (Vemmer and Patel 2013). Among these methods, extrusion based on ionic gelation using alginate is the most popular approach ascribed for BCAs. Hence, Bu. cepaciaand Ps. fluorescens were immobilized in alginate beads with or without skimmed milk (Minaxi 2011). The entomopathogenic fungus Beauveria bassiana and Metarhizium brunneum have also been formulated in alginate beads (Bextine and Thorvilson 2009; Krell et al. 2018).

\subsubsection{Liquid Formulations}

Liquid formulations for BCAs might be of different types, although they basically consist of microbial cultures or simple microbial suspensions in water, mineral or organic oils, polymers or combinations thereof.

Suspension concentrates are conventionally produced by adding a solid active ingredient (which in the case of microbial inoculants means free or immobilized microbial cells) to water or an aqueous solution. They usually contain thickeners (1-3\%), dispersants (1-5\%), and wetting agents (3-8\%). Thickeners and dispersants provide good stability and keep the active ingredient from sedimentation. Wetting agents prevents agglomeration of the particles in suspension and reduce the surface tension of the droplets. An improved version of suspension concentrates is oil dispersions, which consist of a dispersion of a solid active ingredient in a nonaqueous solution, usually oil. The type of oil can vary from paraffinic to aromatic solvent types and vegetable oil or methylated seed oils, although biodegradable oils are often preferred. Emulsions are produced by mixing two (or more) immiscible liquids in the presence of an emulsifier, so that one of the liquids, the dispersed phase, results in production of small droplets into the other phase. Two types can be produced: oil in water $(\mathrm{O} / \mathrm{W})$ or water in oil $(\mathrm{W} / \mathrm{O})$, which is the so-called invert emulsion. Upgrades derived from the above mentioned liquid formulations are suspo-emulsions, which consist of a mixture of a suspension concentrate and an emulsion. The concentration of the microorganisms in the formulation usually ranges from $10 \%$ to $40 \%$ (Brar et al. 2006).

Liquid formulations of biopesticides are common. Ps. fluorescens was formulated in coconut water amended with glycerol or polivinilpirrolidone (PVP) as a suspension concentrate (Anith et al. 2016). An oil dispersion composed of soybean 
oil, an emulsifying-dispersing agent, a structural agent, and glucose, containing conidia of T. asperellum was prepared (Mbarga et al. 2014). W/O emulsions of Ps. fluorescens consisting of water, glycerine, polyethylene glycol, Tween 20 and coconut, rice bran or castor oil reduced disease severity caused by $C$. musae in bananas (Peeran et al. 2014).

\subsubsection{Additives}

In addition to the classical protective substances (e.g., sucrose, glycerol, arabic gum) that improve survival of the microorganisms, formulations might be amended with adjuvants that facilitate mixing and handling, application and effectiveness. For instance, activator adjuvants increase spreading, retention, penetration, washoff resistance, and decreased evaporation rate. They comprise of surfactants and oils. The type of surfactants most commonly used in agriculture is the non-ionic surfactants (e.g., polyoxyethylene surfactants, block copolymer surfactants). Utility adjuvants alter the physical properties of the formulation, thereby helping to minimize handling and application problems. These include emulsifiers (e.g., ethylene oxide), dispersants (e.g., celluloses, PVP), coupling agents (e.g., organosilanes), co-solvents (e.g., alcohol, glycol), stabilizing and compatibility agents (e.g., EDTA, triethanolamine, ammonium sulfate), buffering agents (e.g., citric acid, potassium phosphate), thickeners (e.g., celluloses, polysaccharide gums), stickers (e.g., polysaccharide gums, epoxidized seed oils), spreading agents (e.g., alcohol ethoxylates), humectants (e.g., glycerol, polyethylene glycol, ethylene glycol), foaming and defoaming agents (e.g., dimethylsiloxane, silica-based compounds), UV adsorbents (e.g., titanium dioxide or zinc oxide) and dyes.

\subsubsection{Characterization of Formulations}

The establishment of effective tools for characterization of formulations is of fundamental importance to define the physicochemical and biological properties of a given BCA formulation (such as particle morphology, surface hydrophobicity, cell viability), and to ensure that efficacious products reach the end users. Morphological characterization of carriers and final solid formulations can be studied using highresolution microscopy and laser diffraction or dynamic light. Wettability of surfaces can be determined by contact angle goniometry.

The enumeration of viable cells is typically assessed by simple plate count methods. Most probable number counts are also widely used to estimate cell population. Other methods focusing on cell physiology include biochemical assays allowing the quantification of certain cell components or cell metabolic activity (e.g., flow cytometry); immunological methods such as ELISA; or optical methods such as spectrophotometry or microscopy. 


\subsection{Application Technologies}

BCAs can be delivered to the plants through several means (typically by inoculation of seeds, soil or aerial plant parts) depending on the mode of action of the BCA, the plant growth stage and the type of formulation. Hence, formulations for the control of soil-borne pathogens require a different application approach to that required for the control of above-ground pathogens. Likewise, the method of application of wettable powders, water-dispersible granules, and liquid formulations differs from dry powders and granules.

\subsubsection{Seed Application}

Seed application is a common and practical application technique for the protection of seed and seedlings from seed-borne and soil-borne pathogens. Powders and granules for seed coatings are mostly applied using the slurry method. This method involves mixing the solid with a strong adhesive solution, to form a slurry, which is then applied to the seeds. Liquid inoculants (generally supplemented with adhesives) are typically sprayed onto the seeds. Adhesives commonly used for seed coating include arabic gum, CMC, hydroxypropylmethylcellulose, starch, wheat flour, sucrose, vegetable oils, and non-toxic commercial preparations. Sometimes a superfine powder of limestone $\left(\mathrm{CaCO}_{3}\right)$ is added immediately after coating. Seed coatings can be performed either by hand, rotating drums, large dough cement mixers, mechanical tumbling machines or automated seed coaters. Subsequent drying is performed by forced air using seed drying equipment. Coating and drying can also be performed simultaneously in fluidized beds and seed coaters with integrated dryers by dispersing the seeds on a cushion of pressurized air while applying the formulation.

A major constraint of this application technique is that seeds can be coated only with a limited amount of inoculant, which can be a limiting factor since a threshold of a BCA may be needed for successful biological control. Moreover, if the inoculant is not well attached to the seed, some may be lost during sowing. Factors influencing microbial survival on seed are the release of toxic exudates from seed coat or incompatibility between the inoculant strains and seed-applied chemicals.

\subsubsection{Soil Application}

Soil application is an alternative technique for the application of BCAs against soilborne pathogens and involves the direct application of the formulation into soil, usually in the seeding furrow. Soil application is generally done using granular inoculants, wettable powders, water-dispersible granules or liquid inoculants. They 
are often applied under, above or alongside the seed by using granular applicators. Powder inoculants are also suitable for soil application. However, they are dustier than granular inoculants and therefore less user-friendly. Instead, wettable powders, water-dispersible granules, and liquid formulations can be delivered to the soil by hand or by mechanical spraying equipment, which allows for an even distribution of the formulation over the crop area. Furthermore, they can be delivered directly to the root zone of individual plants by drip irrigation, hydroponic systems or by drenching furrows. Soil application is particularly used when large populations of BCAs need to be introduced to the soil. It avoids damage to fragile seeds and overcomes the adverse effects of seed-applied chemicals.

\subsubsection{Aerial Application}

Aerial application directs BCAs to the above-ground plant parts, particularly to the leaves (foliar application), and it is especially convenient to treat above-ground pathogens. This technique allows for multiple applications of the microbial formulation during crop cultivation and for the control of the location and application rate. This is of great interest as the dosage and frequency of application can be standardized based on each pathosystem. The most effective means of aerial application is the use of spray equipment, which can range from an aerosol can to hand or mechanical equipment, including aircraft. The main disadvantage of aerial application is that its use is mostly limited to the early morning or the late evening, when the temperature is lowest, relative humidity is highest and leaves are turgid, especially in warmer regions. The major hurdle in foliar applications is conserving the viability and threshold inoculum potential of the BCA for effective pathogen/pest control. This still appears to be a major hurdle for the development of effective BCAs for pre-harvest application.

\subsection{Validation Trials}

The evaluation of the efficacy of BCAs formulations is essential for estimating their economic use. In this regard, the European and Mediterranean Plant Protection Organization (EPPO) has set up a number of guidelines (http://pp1.eppo.int/) for the evaluation of direct efficacy, number of trials and phytotoxicity assessments. Additional standards and recommendations can be found in the scientific literature. 


\subsubsection{Evaluation of Efficacy}

The efficacy of a plant protection product is defined as the measure of the overall effect of its application on the agricultural system in which it is used (PP 1/214 (4)). In other words, it is the balance between the positive and the negative effects (on the treated, adjacent and successive crops) of the treatment in performing the desired plant protection activity.

Direct efficacy should be performed under different environmental and agronomic conditions which resembles, as closely as possible, the conditions of practical use. The number of required field trials depends on the crop importance and the pest, the severity of the damage, the cultivar effects, and the impact of soil and climatic factors. For instance, for a major crop, 6-15 trials might be required. All trials should include an untreated control, to indicate both initial pest pressure and development during the duration of the trial, and a reference product. The reference should be an existing microbial product known to be satisfactory in practice. Where the use of an appropriate microbial is not possible, a conventional chemical should be included. Laboratory studies on the mode of action, susceptibility of the target pest or host, dose-response and effect of environmental, agronomic and other factors on the product provide additional supporting data. Other elements of efficacy are development of resistance, phytotoxicity, damage to succeeding crops or adjacent corps, effect on other pests and effect on non-target organisms.

\subsubsection{Phytotoxicity Assays}

Phytotoxicity might be observed on plants at emergence, during growth, and at harvest. Effects might be temporary or longer lasting, and symptoms (modifications in the development cycle, thinning, modifications in colour, necrosis, deformations, effect on quantity and quality of yield) might affect the whole plant or specific plant parts.

According to the EPPO guideline PP 1/135 (4), phytotoxicity of formulations with fungicidal and insecticidal activity can be addressed by appropriate observations in efficacy trials. Only if adverse effects are observed, further trials need to be performed. Specific crop safety trials are always needed for herbicides and seed treatments. Phytotoxicity can also cause poor germination and emergence, especially if seed treatment is used. Germination and emergence tests should be performed in sterilized non-absorbent substrates (e.g., quartz sand), soon after treatment and at appropriate intervals during storage. 


\subsubsection{Damage to Succeeding and Adjacent Crops}

Effects on succeeding crops are also required if the BCA survives in soil for the long term, and there is evidence that suggests that they may be adverse effects on seed germination or plant growth.

\subsubsection{Decision on Acceptable Efficacy}

Decision-making criteria for acceptable efficacy of any biocontrol formulation are that it must offer advantages over no use and that it should perform better (or at least equally) when compared with the reference. Additional factors and criteria that are considered relevant to microbial products when determining acceptable, beneficial levels of efficacy need to be considered. This should be considered in the context of BCAs delivering lower amounts of control or more variable performance than would be expected for conventional agrochemicals. These factors include offering an alternative mode of action, valuable uses, chemical residue management or specific compatibility with integrated pest management systems and organic farming. In addition to being effective over a wide range of crops and against several pests and showing great compatibility with conventional agricultural practices, lower probability of resistance and fewer undesirable effects.

\subsection{Conclusions and Future Prospects}

Increasing environmental concerns and the legislation that arises from these is seriously restricting the use of chemical pesticides worldwide, thus creating an urgent need for safer and more environmentally friendly products. Microbial BCAs emerged as a promising strategy to assist crops to fight pathogens. It is now widely known that formulations play a key role in helping microbial BCAs to undertake the long path that connects laboratory testing and field application. Microbial BCAs have been conventionally formulated as granules, wettable powders, and liquids for application as seed treatment, soil drenches, or foliar sprays. Yet, combining biocontrol formulation know-how with advanced technologies from other disciplines (e.g., spray drying, encapsulation) could drive to the development of more efficient and stable formulations. From a technical point of view, this requires a thorough understanding of the interactions occurring among the BCA, formulation components and the environment, as well as understanding of practical applicability.

While developing sophisticated methods for development and application of biocontrol formulations, guidelines on efficacy evaluation and field-testing should be continuously revised to help to deliver proof of efficacy and assist biopesticides to come on the market. 
Commercialisation of biocontrol products is steadily growing worldwide, but in absence of effective regulations penetration of biological products in agricultural market is still slow, especially in the European Union, where registration process is complex and time-consuming. Existing regulation of biopesticides vary from country to country and requirements for registration are often similar to those of chemical substances. The global harmonization of specific biopesticide regulations would undoubtedly overcome these limitations and encourage commercialization of microbial-based biopesticides worldwide. To date, the major steps towards this harmonization have been taken by various global agencies such as the Organization for Economic and Co-Operative Development, International Organization for Biological Control, and EPPO, but success is limited.

Unification of policymaking processes is even more necessary in view of climate change that may alter patterns of pests and diseases' emergence (Elad and Pertot 2013). So much so that it has been predicted that if global warming continues many pathogens will spread in new geographic areas, where they will come in contact with new hosts. Similarly, climate change may negatively impact plant resistance mechanisms making them more susceptible to pathogens attacks (Elad and Pertot 2013). Under worst-case scenarios, where chemicals have been banned and/or plants are more susceptible, the containment of some pest and diseases may not be feasible in absence of effective microbial-based biopesticides. It is also worth noting that, BCAs' efficacy depends on environmental factors.

Future research should focus on improving production, formulation and delivery of BCAs. Apart from this, demonstration trials with high-quality products and simpler and universal regulations are crucially needed to assist commercialisation of biopesticides. An increase in research efforts to provide highly efficient biocontrol formulations for agricultural production is expected to pay off in the long term, replacing agricultural chemicals and making agriculture more sustainable and productive.

Acknowledgments This work was supported by the European Union's Horizon 2020 research and innovation programme under the Marie Skłodowska-Curie grant agreement no. 797028.

\section{References}

Abbasi PA, Khabbaz SE, Zhang L (2016) Bioformulations of novel indigenous rhizobacterial strains for managing soilborne pathogens. In: Arora NK, Mehnaz S, Balestrini R (eds) Bioformulations: for sustainable agriculture. Springer, New Delhi, pp 147-163

Amer GA, Utkhede RS (2000) Development of formulations of biological agents for management of root rot of lettuce and cucumber. Can J Microbiol 46:809-816

Anith KN, Vyshakhi AS, Viswanathan A, Varkey S, Aswini S (2016) Population dynamics and efficiency of coconut water based liquid formulation of Pseudomonas fluorescens AMB-8. J Trop Agric 54:184-189

Arora NK, Khare E, Naraian R, Maheshwari DK (2008) Sawdust as superior carrier for production of multipurpose bioinoculant using plant growth promoting rhizobial and pseudomonad strains and their impact on protuctivity of Trifolium repense. Curr Sci 95:90-94 
Benhamou N, Bélanger RR, Rey P, Tirilly Y (2001) Oligandrin, the elicitin-like protein produced by the mycoparasite Pythium oligandrum, induces systemic resistance to Fusarium crown and root rot in tomato plants. Plant Physiol Biochem 39:681-696. https://doi.org/10.1016/ S0981-9428(01)01283-9

Berninger T, González López Ó, Bejarano A, Preininger C, Sessitsch A (2018) Maintenance and assessment of cell viability in formulation of non-sporulating bacterial inoculants. Microb Biotechnol 11:277-301. https://doi.org/10.1111/1751-7915.12880

Bextine BR, Thorvilson HG (2009) Field applications of bait-formulated Beauveria bassiana alginate pellets for biological control of the red imported fire ant (Hymenoptera: Formicidae). Environ Entomol 31:746-752. https://doi.org/10.1603/0046-225x-31.4.746

Brar SK, Verma M, Tyagi RD, Valéro JR (2006) Recent advances in downstream processing and formulations of Bacillus thuringiensis based biopesticides. Process Biochem 41:323-342. https://doi.org/10.1016/j.procbio.2005.07.015

Burkhead KD, Schisler DA, Slininger PJ (1994) Pyrrolnitrin production by biological control agent Pseudomonas cepacia B37w in culture and in colonized wounds of potatoes. Appl Environ Microbiol 60:2031-2039

Cabrefiga J, Francés J, Montesinos E, Bonaterra A (2014) Improvement of a dry formulation of Pseudomonas fluorescens EPS62e for fire blight disease biocontrol by combination of culture osmoadaptation with a freeze-drying lyoprotectant. J Appl Microbiol 117:1122-1131. https:// doi.org/10.1111/jam. 12582

Chowdhury SP, Uhl J, Grosch R, Alquéres S, Pittroff S, Dietel K, Schmitt-Kopplin P, Borriss R, Hartmann A (2015) Cyclic lipopeptides of Bacillus amyloliquefaciens subsp. plantarum colonizing the lettuce rhizosphere enhance plant defense responses toward the bottom rot pathogen Rhizoctonia solani. Mol Plant-Microbe Interact 28:984-995. https://doi.org/10.1094/ MPMI-03-15-0066-R

Di Francesco A, Ugolini L, Lazzeri L, Mari M (2015) Production of volatile organic compounds by Aureobasidium pullulans as a potential mechanism of action against postharvest fruit pathogens. Biol Control 81:8-14. https://doi.org/10.1016/J.BIOCONTROL.2014.10.004

Elad Y, Pertot I (2013) Climate change impact on plant pathogens and plant diseases. Comb Clim Chang Agric Perspect 7528:183-211. https://doi.org/10.1201/b14056

Farace G, Fernandez O, Jacquens L, Coutte F, Krier F, Jacques P, Clément C, Barka EA, Jacquard C, Dorey S (2015) Cyclic lipopeptides from Bacillus subtilis activate distinct patterns of defence responses in grapevine. Mol Plant Pathol 16:177-187. https://doi.org/10.1111/mpp.12170

Haas D, Défago G (2005) Biological control of soil-borne pathogens by fluorescent pseudomonads. Nat Rev Microbiol 3:307-319. https://doi.org/10.1038/nrmicro1129

IPPC (2017) Plant health and food security. Rome

Islam MT, Hashidoko Y, Deora A, Ito T, Tahara S (2005) Suppression of damping-off disease in host plants by the rhizoplane bacterium Lysobacter sp. strain SB-K88 is linked to plant colonization and antibiosis against soilborne Peronosporomycetes. Appl Environ Microbiol 71:3786 LP-3783796. https://doi.org/10.1128/AEM.71.7.3786-3796.2005

Kempf H, Bauer P, Schroth M (1993) Herbicolin A associated with crown and roots of wheat after seed treatment with Erwinia herbicola B247. Phytopathology 83:213-126

Keswani C, Bisen K, Singh V, Sarma BK, Singh HB (2016) Formulation technology of biocontrol agents: present status and future prospects. In: Arora NK, Raff SM, Balestrini R (eds) Bioformulations: for sustainable agriculture. Springer, Varanasi, pp 35-52. https://doi. org/10.1007/978-81-322-2779-3

Khan A, Singh P, Srivastava A (2018) Synthesis, nature and utility of universal iron chelator - Siderophore: a review. Microbiol Res 212-213:103-111. https://doi.org/10.1016/J. MICRES.2017.10.012

Kilic-Ekici O, Yuen GY (2003) Induced resistance as a mechanism of biological control by Lysobacter enzymogenes strain C3. Phytopathology 93:1103-1110. https://doi.org/10.1094/ PHYTO.2003.93.9.1103 
Kiss L (2008) Chapter 3 intracellular mycoparasites in action: interactions between powdery mildew fungi and Ampelomyces. In: Avery SV, Stratford M, Van West P (eds) British Mycological Society symposia series. Academic, pp 37-52. https://doi.org/10.1016/S0275-0287(08)80045-8

Koumoutsi A, Chen X-H, Henne A, Liesegang H, Hitzeroth G, Franke P, Vater J, Borriss R (2004) Structural and functional characterization of gene clusters directing nonribosomal synthesis of bioactive cyclic lipopeptides in Bacillus amyloliquefaciens strain FZB42. J Bacteriol 186:1084 LP-1081096. https://doi.org/10.1128/JB.186.4.1084-1096.2004

Krell V, Jakobs-Schoenwandt D, Vidal S, Patel AV (2018) Encapsulation of Metarhizium brunneum enhances endophytism in tomato plants. Biol Control 116:62-73. https://doi.org/10.1016/j. biocontrol.2017.05.004

Leclère V, Béchet M, Adam A, Guez J-S, Wathelet B, Ongena M, Thonart P, Gancel F, CholletImbert M, Jacques P (2005) Mycosubtilin overproduction by Bacillus subtilis BBG100 enhances the organism's antagonistic and biocontrol activities. Appl Enviro Microbiol 71:4577 LP-4574584. https://doi.org/10.1128/AEM.71.8.4577-4584.2005

Li S, Jochum CC, Yu F, Zaleta-Rivera K, Du L, Harris SD, Yuen GY (2008) An antibiotic complex from Lysobacter enzymogenes strain C3: antimicrobial activity and role in plant disease control. Phytopathology 98:695-701. https://doi.org/10.1094/PHYTO-98-6-0695

Lindow SE (1987) Competitive exclusion of epiphytic bacteria by ice Pseudomonas syringae mutants. Appl Environ Microbiol 53:2520-2527

Lobo CB, Juárez Tomás MS, Viruel E, Ferrero MA, Lucca ME (2019) Development of low-cost formulations of plant growth-promoting bacteria to be used as inoculants in beneficial agricultural technologies. Microbiol Res 219:12-25. https://doi.org/10.1016/j.micres.2018.10.012

Mbarga JB, Begoude BAD, Ambang Z, Meboma M, Kuate J, Schiffers B, Ewbank W, Dedieu L, Hoopen GM (2014) A new oil-based formulation of Trichoderma asperellum for the biological control of cacao black pod disease caused by Phytophthora megakarya. Biol Control 77:15-22. https://doi.org/10.1016/J.BIOCONTROL.2014.06.004

Minaxi J (2011) Efficacy of rhizobacterial strains encapsulated in nontoxic biodegradable gel matrices to promote growth and yield of wheat plants. Appl Soil Ecol 48:301-308. https://doi. org/10.1016/j.apsoil.2011.04.007

Mohamed N, Lherminier J, Farmer MJ, Fromentin J, Béno N, Houot V, Milat ML, Blein JP (2007) Defense responses in grapevine leaves against Botrytis cinerea induced by application of a Pythium oligandrum strain or its Elicitin, Oligandrin, to roots. Phytopathology 97:611-620. https://doi.org/10.1094/PHYTO-97-5-0611

Morgan CA, Herman N, White PA, Vesey G (2006) Preservation of micro-organisms by drying; a review. J Microbiol Methods 66:183-193. https://doi.org/10.1016/j.mimet.2006.02.017

Ongena M, Jourdan E, Adam A, Paquot M, Brans A, Joris B, Arpigny JL, Thonart P (2007) Surfactin and fengycin lipopeptides of Bacillus subtilis as elicitors of induced systemic resistance in plants. Environ Microbiol 9:1084-1090. https://doi.org/10.1111/j.1462-2920.2006.01202.x

Peeran MF, Krishnan N, Thangamani PR, Gandhi K, Thiruvengadam R, Kuppusamy P (2014) Development and evaluation of water-in-oil formulation of Pseudomonas fluorescens (FP7) against Colletotrichum musae incitant of anthracnose disease in banana. Eur J Plant Pathol 138:167-180. https://doi.org/10.1007/s10658-013-0320-6

Pieterse CMJ, Zamioudis C, Berendsen RL, Weller DM, Van Wees SCM, Bakker PAHM (2014) Induced systemic resistance by beneficial microbes. Annu Rev Phytopathol 52:347-375. https://doi.org/10.1146/annurev-phyto-082712-102340

PP 1/135 (4) Phytotoxicity assessment (2014) EPPO Bulletin. https://doi.org/10.1111/epp.12134

PP 1/214 (4) Principles of acceptable efficacy (2017) EPPO Bulletin. https://doi.org/10.1111/ epp. 12395

Puopolo G, Giovannini O, Pertot I (2014) Lysobacter capsici AZ78 can be combined with copper to effectively control Plasmopara viticola on grapevine. Microbiol Res 169:633-642. https:// doi.org/10.1016/j.micres.2013.09.013 
Puopolo G, Tomada S, Pertot I (2018) The impact of the omics era on the knowledge and use of Lysobacter species to control phytopathogenic micro-organisms. J Appl Microbiol 124:15-27. https://doi.org/10.1111/jam.13607

Rey P, Le Floch G, Benhamou N, Tirilly Y (2008) Pythium oligandrum biocontrol: its relationships with fungi and plants. In: Ait Barka E, Clement C (eds) Plant-microbe interactions. Research Signpost, Trivandrum, pp 43-67

Stephan D, Da Silva APM, Bisutti IL (2016) Optimization of a freeze-drying process for the biocontrol agent Pseudomonas spp. and its influence on viability, storability and efficacy. Biol Control 94:74-81. https://doi.org/10.1016/j.biocontrol.2015.12.004

Thomashow LS, Weller DM, Bonsall RF, Pierson LS (1990) Production of the antibiotic phenazine-1-carboxylic acid by fluorescent pseudomonas species in the rhizosphere of wheat. Appl Environ Microbiol 56:908-912

Thrane C, Nielsen TH, Nielsen MN, Sørensen J, Olsson S (2000) Viscosinamide-producing Pseudomonas fluorescens DR54 exerts a biocontrol effect on Pythium ultimum in sugar beet rhizosphere. FEMS Microbiol Ecol 33:139-146. https://doi.org/10.1111/j.1574-6941.2000. tb00736.x

Tomada S, Sonego P, Moretto M, Engelen K, Pertot I, Perazzolli M, Puopolo G (2017) Dual RNA-Seq of Lysobacter capsici AZ78 - Phytophthora infestans interaction shows the implementation of attack strategies by the bacterium and unsuccessful oomycete defense responses. Environ Microbiol 19:4113-4125. https://doi.org/10.1111/1462-2920.13861

Tomprefa N, McQuilken MP, Hill RA, Whipps JM (2009) Antimicrobial activity of Coniothyrium minitans and its macrolide antibiotic macrosphelide a. J Appl Microbiol 106:2048-2056. https://doi.org/10.1111/j.1365-2672.2009.04174.x

Vemmer M, Patel AV (2013) Review of encapsulation methods suitable for microbial biological control agents. Biol Control 67:380-389. https://doi.org/10.1016/j.biocontrol.2013.09.003

Vinale F, Sivasithamparam K, Ghisalberti EL, Marra R, Woo SL, Lorito M (2008) Trichodermaplant-pathogen interactions. Soil Biol Biochem 40:1-10. https://doi.org/10.1016/J. SOILBIO.2007.07.002

Whipps JM, Gerlagh M (1992) Biology of Coniothyrium minitans and its potential for use in disease biocontrol. Mycol Res 96:897-907. https://doi.org/10.1016/S0953-7562(09)80588-1

Wu L, Huang Z, Li X, Ma L, Gu Q, Wu H, Liu J, Borriss R, Wu Z, Gao X (2018) Stomatal closure and SA-, JA/ET-signaling pathways are essential for Bacillus amyloliquefaciens FZB42 to restrict leaf disease caused by Phytophthora nicotianae in Nicotiana benthamiana. Front Microbiol 9:847

Yánez-Mendizábal V, Viñas I, Usall J, Torres R, Solsona C, Abadias M, Teixidó N (2012) Formulation development of the biocontrol agent Bacillus subtilis strain CPA-8 by spraydrying. J Appl Microbiol 112:954-965. https://doi.org/10.1111/j.1365-2672.2012.05258.x

Open Access This chapter is licensed under the terms of the Creative Commons Attribution 4.0 International License (http://creativecommons.org/licenses/by/4.0/), which permits use, sharing, adaptation, distribution and reproduction in any medium or format, as long as you give appropriate credit to the original author(s) and the source, provide a link to the Creative Commons license and indicate if changes were made.

The images or other third party material in this chapter are included in the chapter's Creative Commons license, unless indicated otherwise in a credit line to the material. If material is not included in the chapter's Creative Commons license and your intended use is not permitted by statutory regulation or exceeds the permitted use, you will need to obtain permission directly from the copyright holder.

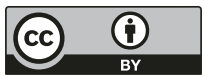

